\title{
The Booroola mutation in sheep is associated with an alteration of the bone morphogenetic protein receptor-IB functionality
}

\author{
S Fabre, A Pierre, C Pisselet, P Mulsant ${ }^{1}$, F Lecerf $^{1}$, J Pohl ${ }^{2}$, \\ $\mathbf{P}$ Monget and $\mathbf{D}$ Monniaux \\ INRA, Physiologie de la Reproduction et des Comportements, UMR 6073 INRA-CNRS-Université François Rabelais, 37380 Nouzilly, France \\ ${ }^{1}$ INRA, Laboratoire de Génétique Cellulaire, BP 27, 31326 Castanet-Tolosan, France \\ ${ }^{2}$ Biopharm Gmbh, Czernyring 22, D-69115 Heidelberg, Germany \\ (Requests for offprints should be addressed to D Monniaux; Email: Danielle.Monniaux@tours.inra.fr)
}

\begin{abstract}
The hyperprolificacy phenotype of Booroola ewes is due to the presence of the $\mathrm{FecB}^{\mathrm{B}}$ allele at the $\mathrm{FecB}$ locus, recently identified as a single amino acid substitution (Q249R) in the bone morphogenetic protein (BMP) type-IB receptor (BMPR1B), and is associated with a more precocious differentiation of ovarian granulosa cells (GCs). To evaluate the consequences of the Booroola mutation on BMPR1B functions, the action of ligands of the transforming growth factor- $\beta$ (TGF $\beta$ )/BMP family that act through (growth and differentiation factor-5, BMP-4) or independently of (activin A, TGF $\beta-1$ ) BMPR1B were studied on primary cultures of GCs from homozygous $\mathrm{FecB}^{+}$and $\mathrm{FecB}^{\mathrm{B}}$ ewes. All the tested TGF $\beta / \mathrm{BMP}$ family ligands inhibited progesterone secretion by $\mathrm{FecB}^{+}$GCs. Those inhibitory effects were lower for GCs from preovulatory (5-7 $\mathrm{mm}$ diameter) than from small antral follicles (1$3 \mathrm{~mm}$ diameter). The presence of the Booroola mutation
\end{abstract}

was associated with a 3 - to 4 -fold $(P<0 \cdot 001)$ decreased responsiveness of $\mathrm{GCs}$ from $\mathrm{FecB}^{\mathrm{B}}$ compared with $\mathrm{FecB}^{+}$ small follicles to the action of BMPR1B ligands. In contrast, TGF $\beta-1$ and activin A had similar inhibitory effects on progesterone secretion by GCs from $\mathrm{FecB}^{+}$and $\mathrm{FecB}^{\mathrm{B}}$ small follicles. No difference between genotypes was observed with GCs from preovulatory follicles. In transfection experiments with HEK-293 cells, co-expression of $\mathrm{FecB}^{+}$BMPR1B and BMPR2 resulted in a 2.6-fold $(P<0 \cdot 01)$ induction of the activity of a BMP-specific luciferase reporter construct by BMP-4. Interestingly, no response to BMP-4 was observed when cells were transfected with the $\mathrm{FecB}^{\mathrm{B}}$ form of the BMPR1B receptor. Overall, these data strongly suggest that the Q249R mutation is associated with a specific alteration of BMPR1B signaling in hyperprolific Booroola ewes.

Journal of Endocrinology (2003) 177, 435-444

\section{Introduction}

Booroola is an autosomal mutation identified on the basis of segregational studies on litter size and ovulation rate (Davis et al. 1982, Piper et al. 1985). The Booroola phenotype has a Mendelian pattern of segregation indicating that it is caused by a major gene, named FecB, which has additive effects on ovulation rate. The alleles are called $\mathrm{FecB}^{\mathrm{B}}$ for the high prolificacy allele and $\mathrm{FecB}^{+}$for the wild-type allele. In sexually mature ewes, the most consistent feature reported for $\mathrm{FecB}^{\mathrm{B}}$-carrier ewes is that ovarian follicles ovulate at a significantly smaller diameter than do those in non-carrier animals. In particular, based on the segregation of the ovulation rate in Merino flocks, the genotypes of the ewes are classified as homozygous non-carrier $\left(\mathrm{FecB}^{+} / \mathrm{FecB}^{+}\right)$with an ovulation rate of one or two and a size of ovulatory follicles of $7 \mathrm{~mm}$ diameter, heterozygous carriers $\left(\mathrm{FecB}^{\mathrm{B}} / \mathrm{FecB}^{+}\right)$with an ovulation rate of three or four and a size of ovulatory follicles of
4-5 mm diameter, and homozygous carriers $\left(\mathrm{FecB}^{\mathrm{B}} /\right.$ $\mathrm{FecB}^{\mathrm{B}}$ ) with more than five ovulations per cycle and a size of ovulatory follicles of 3-4 mm diameter (Davis et al. 1982). In the ovary, during follicular growth, the decrease in proliferative activity and the increase in the expression of the main markers of final follicular maturation, in particular luteinizing hormone receptor and aromatase, appear more precociously in granulosa cells (GCs) from homozygous $\mathrm{FecB}^{\mathrm{B}}$ than in $\mathrm{GCs}$ from $\mathrm{FecB}^{+}$ewes. Consequently, there are fewer GCs in $\mathrm{FecB}^{\mathrm{B}}$ than in $\mathrm{FecB}^{+}$preovulatory follicles, but the total number of GCs in preovulatory follicles per animal, as well as the ovarian secretion rate of steroids and inhibin, are similar in both genotypes (for a review see Baird \& Campbell 1998).

Recently, the Q249R mutation in the coding sequence of the bone morphogenetic protein (BMP) type-IB receptor $(\mathrm{BMPR} 1 \mathrm{~B})$ gene $(B M P R 1 B)$ was found to be fully associated with the Booroola phenotype (Mulsant et al. 2001, Souza et al. 2001, Wilson et al. 2001). BMPR1B 
belongs to the family of receptors for transforming growth factor- $\beta$ (TGF $\beta$ )-like factors that is composed of several ligands such as TGF $\beta$, activins, BMPs, growth and differentiation factors (GDFs) and Mullerian inhibiting substance (Derynck \& Feng 1997). Ligands of the TGF $\beta$ / BMP family exert their biological effects through specific Ser/Thr-kinase transmembrane receptors, type I and type II. BMPR1B is one of the specific type I receptors for the subfamily of BMP and GDF ligands. Ligand binding induces the formation of heterotetramers of type I and type II receptors, leading to the activation of a specific intracellular signaling pathway by phosphorylation of Smad proteins (Derynck \& Feng 1997, Miyazono 1999).

In sheep, we have previously shown that BMPR1B ligands, GDF-5 and BMP-4, inhibit progesterone secretion by ovine GCs isolated from small antral follicles (1-3 mm diameter) in vitro (Mulsant et al. 2001). Moreover, this inhibitory effect is attenuated with $\mathrm{FecB}^{\mathrm{B}}$ GCs when compared with $\mathrm{FecB}^{+}$GCs recovered from 1-3 mm diameter follicles in both genotypes, suggesting that Q249R substitution in BMPR1B may alter its function (Mulsant et al. 2001). However, as said above, it has been previously shown that terminal differentiation of GCs in vivo is acquired at a smaller follicular size in the $\mathrm{FecB}^{\mathrm{B}}$ than in $\mathrm{FecB}^{+}$genotype (Henderson et al. 1985, 1987, McNatty et al. 1986, Monniaux et al. 2000). So, it can be argued that the observed decrease in responsiveness of $\mathrm{FecB}^{\mathrm{B}}$ GCs to BMPR1B ligands might be due to a more advanced cellular differentiation stage compared with $\mathrm{FecB}^{+} \mathrm{GCs}$ of the same follicle size class, rather than to a direct effect of the mutation.

To address this issue, we have performed an overall study of the effects of different elements of the BMP/ TGF $\beta$ system (GDF-5, BMP-4, activin A and TGF $\beta-1)$ on $\mathrm{GC}$ from $\mathrm{FecB}^{+}$and $\mathrm{FecB}^{\mathrm{B}}$ follicles. In particular, we have studied the effect of GDF-5 and BMP-4 on steroidogenesis and proliferation of GCs isolated from ovine follicles of both genotypes at different stages of terminal follicular development. To assess the specificity of the differential effect observed with BMPR1B ligands on $\mathrm{FecB}^{+}$and $\mathrm{FecB}^{\mathrm{B}}$ GCs, we have studied the effects of TGF $\beta-1$ and activin $A$, which act independently of BMPR1B (Miyazono et al. 2001) and which inhibit progesterone production by GCs in different species (Shukovski \& Findlay 1990, Miro et al. 1991, Kubota et al. 1994, Ford \& Howard 1997). Moreover, we have tested the consequences of the Q249R mutation on BMPR1B signaling function in transient transfection experiments of BMP-responsive human epithelial kidney cells, HEK-293.

\section{Materials and Methods}

\section{Animals}

Cyclic $\mathrm{FecB}^{\mathrm{B}}$ and $\mathrm{FecB}^{+}$Mérinos d'Arles ewes (genotyped as described (Mulsant et al. 2001)) were treated with intravaginal progestagen sponges (fluorogestone acetate, $40 \mathrm{mg}$; Intervet, Angers, France) for 13 days to synchronize estrus. Ovaries from both genotypes were recovered after castration in the late follicular phase, $36 \mathrm{~h}$ after sponge removal. All procedures were approved by the Agricultural and Scientific Research Government Committees in accordance with the guidelines for Care and Use of Agricultural Animals in Agricultural Research and Teaching (approval A37801).

\section{Granulosa cell cultures}

Briefly, in each independent culture experiment, ovarian follicles from four $\mathrm{FecB}^{\mathrm{B}}$ and four $\mathrm{FecB}^{+}$ewes were quickly dissected, pooled and classified according to size (i.e. small antral follicles, $1-3 \mathrm{~mm}$ in diameter; medium follicles, $3 \cdot 5-4.5 \mathrm{~mm}$; and large follicles, 5-7 mm) and genotype. Large follicles were found only in the $\mathrm{FecB}^{+}$ genotype. Large follicles from $\mathrm{FecB}^{+}$ewes and medium follicles from $\mathrm{FecB}^{\mathrm{B}}$ ewes were classified as preovulatory follicles. GCs were recovered from each class size follicles as previously described (Monniaux \& Pisselet 1992). $\mathrm{FecB}^{\mathrm{B}}$ and $\mathrm{FecB}^{+}$GCs suspensions were seeded at 100000 viable cells/well in 96-well plates and cultured for $96 \mathrm{~h}$ at $37^{\circ} \mathrm{C}$ with $5 \% \mathrm{CO}_{2}$ in serum-free McCoy's $5 \mathrm{a}$ medium (Sigma, L'Isle d'Abeau Chesnes, France) containing insulin-like growth factor-I (IGF-I) $(10 \mathrm{ng} / \mathrm{ml}$; Ciba-Geigy, Saint-Aubin, Switzerland), according to a previously described method (Campbell et al. 1996). Cultures were performed with or without various concentrations $(1,5,10$ or $50 \mathrm{ng} / \mathrm{ml})$ of dimeric recombinant human GDF-5 (Biopharm GmbH, Heidelberg, Germany), recombinant human BMP-4 (Genetics Institute, Inc., Cambridge, MA, USA), recombinant human activin A (National Hormone Pituitary Program, National Institute of Diabetes, Digestive and Kidney Diseases, Bethesda, MD, USA) or $0 \cdot 2,1,5$ or $10 \mathrm{ng} / \mathrm{ml}$ recombinant human TGF $\beta-1$ (Sigma). Monomeric recombinant human GDF-5 (50 ng/ml; Biopharm) was used as a negative control. Each combination of treatments was tested in triplicate in each of four independent culture experiments. Culture media were partially replaced (180 of $250 \mu \mathrm{l}$ ) at $48 \mathrm{~h}$. Media conditioned between 48 and $96 \mathrm{~h}$ of culture were collected at $96 \mathrm{~h}$ and stored at $-20{ }^{\circ} \mathrm{C}$ prior to progesterone assay. At the end of the culture, the number of cells per well was estimated after trypsinization by counting an aliquot of each resulting cell suspension with a hemacytometer under a phase contrast microscope.

\section{Progesterone RIA}

Progesterone amounts (ng/50000 cells) in the culture media from each experiment were measured by RIA in 
the same assay as described by Saumande (1991). The limit of detection of the assay was $12 \mathrm{pg} /$ tube and the intra-assay coefficient of variation was $10 \%$.

\section{Detection of cytochrome P450 side chain cleavage (P450scc)}

GCs from $\mathrm{FecB}^{+}$ewes were cultured as described above. Each combination of treatments was tested in three independent cultures. After $96 \mathrm{~h}$ of culture, media were removed and GCs were resuspended in lysis buffer (0.125 M Tris- $\mathrm{HCl}, 4 \%$ SDS, 20\% glycerol). Protein concentration was determined by a colorimetric assay (BC Assay Kit; Uptima Interchim, Montluçon, France). The protein samples $(60 \mu \mathrm{g})$ were fractionated using SDSPAGE in $12 \%$ polyacrylamide gels and transferred to nitrocellulose membranes (Schleicher \& Schuell, Ecquevilly, France). The same samples were run in duplicate, half of the membrane was used for P450scc detection and the second half for actin detection, used as loading control. P450scc was detected using a rabbit polyclonal antibody raised against P450scc (dilution 1/1000; Chemicon Euromedex, Mundolsheim, France), followed by incubation with peroxidase conjugated anti-rabbit IgG (dilution 1/20 000; Interchim, Montluçon, France). Actin was revealed using a mouse monoclonal anti-actin antibody (dilution 1/1000; Sigma) followed by incubation with peroxidase-conjugated anti-mouse IgG (dilution 1/20 000, Bio-Rad, Marnes-la-Coquette, France). The protein bands were detected using ECL detection reagents (Amersham Pharmacia Biotech, Orsay, France).

\section{Cell proliferation}

In six independent cultures for both genotypes, proliferation was assessed by studying $\left[{ }^{3} \mathrm{H}\right]$ thymidine $(0 \cdot 25 \mu \mathrm{Ci} / \mathrm{ml}$ (1 Ci=37 GBq); DuPont de Nemours, Les Ulis, France) incorporation for $2 \mathrm{~h}$ by GCs from small follicles, after $48 \mathrm{~h}$ of culture in the absence or in presence of GDF-5 (50 ng/ml), BMP-4 (50 ng/ml) or IGF-I (10 ng/ml) as a positive control. The labeling index (percentage of $\left[{ }^{3} \mathrm{H}\right]$ thymidine-labeled cells) was determined as described (Monniaux et al. 2000).

\section{Plasmids and transient transfection}

The $\mathrm{FecB}^{+}$and $\mathrm{FecB}^{\mathrm{B}}$ BMPR1B expression plasmids were generated using RT-PCR as described (Mulsant et al. 2001) and cloning of the PCR products into pSG5 vector (Stratagene, Amsterdam, The Netherlands). The presence of the Booroola mutation was verified by sequencing. pCMV-BMPR2, a human BMP receptor type II expression plasmid (Liu et al. 1995) and 12 GCCG-lux, a BMP-specific luciferase reporter construct (Kusanagi et al. 2000) were kindly provided by J Massagué and $\mathrm{M}$ Kawabata respectively.

Human epithelial kidney HEK-293 cells were seeded at 40000 cells/well in 48-well plates and cultured for $24 \mathrm{~h}$ in
Dulbecco's modified Eagle's medium (DMEM) supplemented with 10\% fetal calf serum (FCS), $3 \mathrm{mM}$ glutamine and antibiotics $(10 \mathrm{U} / \mathrm{ml}$ penicillin, $100 \mathrm{pg} / \mathrm{ml}$ streptomycin, $2 \cdot 5 \mu \mathrm{g} / \mathrm{ml}$ Fungizone). Then, plasmids and reporter gene (200 ng of each construct/well) were transiently transferred to cells using Dac30 transfection reagent for $3 \mathrm{~h}$ with a DNA/Dac30 ratio of $1 / 2(\mathrm{w} / \mathrm{w})$ as specified by the manufacturer (Eurogentec SA, Seraing, Belgium). After transfection, cells were starved in serum-free DMEM and incubated for $24 \mathrm{~h}$ with or without $100 \mathrm{ng} /$ ml BMP-4 (Genetics Institute) before luciferase assays (Promega, Charbonnières, France). Each combination of plasmids was tested in triplicate in each culture and in three independent cultures.

\section{Data analysis}

All experimental data are presented as means \pm S.E.M. For results of progesterone secretion, important variations were observed between independent cultures. Accordingly, data were expressed as percentages of the amount of progesterone secreted by 50000 cells cultured in the absence of TGF $\beta /$ BMP family ligands. Absolute amounts of progesterone secreted in basal condition were as follow: $\mathrm{FecB}^{+} \quad$ small follicles $=73 \cdot 1 \pm 18.3 \mathrm{ng} \quad(n=8) ; \quad \mathrm{FecB}^{+}$ medium follicles $=10 \cdot 3 \pm 5 \cdot 5 \mathrm{ng} \quad(n=4) ; \mathrm{FecB}^{+}$preovulatory follicles $=86 \cdot 6 \pm 39 \cdot 2 \mathrm{ng} \quad(n=8) ; \mathrm{FecB}^{\mathrm{B}}$ small follicles $=66 \cdot 5 \pm 12 \cdot 5 \mathrm{ng} \quad(n=8) ; \quad \mathrm{FecB}^{\mathrm{B}}$ preovulatory follicles $=137 \cdot 2 \pm 62 \cdot 5 \mathrm{ng}(n=8)$. For each follicle size class, or each genotype, the effects of ligands on progesterone secretion were analyzed using two-way ANOVA in order to appreciate the 'ligand effect' as well as the 'culture effect'. For comparison of the effects of TGF $\beta$ / BMP ligands between follicle sizes or between genotypes, means were compared using three-way ANOVA to allow for 'ligand effect', 'culture effect' and 'follicle size effect' or 'genotype effect'. For luciferase assays, in basal as well as in BMP-induced conditions, the effect of different combinations of plasmids was assessed by two-way ANOVA to allow for 'culture effect' and 'plasmid effect'. The effect of BMP-4 for each combination of plasmids was assessed by two-way ANOVA to allow for 'culture effect' and 'BMP-4 effect'. Post-hoc comparisons were performed with the Scheffe and Newman-Keuls tests. For the thymidine labeling index, comparisons of means between control and ligand-treated conditions were performed using paired $t$-tests for each genotype. For all analysis, differences with $P>0.05$ were considered as not significant.

\section{Results}

Responsiveness of GCs from $\mathrm{FecB}^{+}$ewes to BMPR $1 B$ ligands: effect of follicular size

Addition of increasing doses of GDF-5 or BMP-4 led to a dose-dependent inhibition of progesterone secretion by 
GCs from small, as well as medium and preovulatory $\mathrm{FecB}^{+}$follicles (Fig. 1A). In contrast, the monomeric form of GDF-5, used as a negative control, had no effect at the highest dose tested $(50 \mathrm{ng} / \mathrm{ml})$. Moreover, accumulation of immunoreactive P450scc decreased in the presence of BMP-4 (Fig. 1B). So, inhibition of progesterone secretion by BMP-4 might be, at least partly, due to inhibition of P450scc accumulation, a rate-limiting step in progesterone synthesis.

GCs from medium and preovulatory follicles were less responsive to GDF-5 and BMP-4 action than those from small follicles. Indeed, the first dose of GDF-5 that was effective in inhibiting progesterone secretion was $1 \mathrm{ng} / \mathrm{ml}$ with GCs from small follicles compared with $10 \mathrm{ng} / \mathrm{ml}$ with GCs from larger follicles (Fig. 1A). Moreover, at the highest dose used (50 ng/ml), GDF-5 and BMP-4 actions were 2- and 3-fold more effective with GCs from small follicles compared with more mature GCs respectively $(P<0 \cdot 05)$. Overall, these results indicate that the effects of BMPR1B ligands on GCs decreased during terminal follicular development in ewes.

Comparison of $\mathrm{FecB}^{+}$and $\mathrm{FecB}^{B}$ genotypes for responsiveness to $B M P R 1 B$ ligands

GDF-5 and BMP-4 (50 ng/ml) exhibited inhibitory actions on progesterone secretion by $\mathrm{FecB}^{\mathrm{B}}$ GCs from both small follicles (as shown previously (Mulsant et al. 2001)) and preovulatory follicles (Fig. 2A). Monomeric GDF-5 $(50 \mathrm{ng} / \mathrm{ml})$ was without effect on progesterone production. As previously shown as well, GCs from small follicles were 3- and 4-fold less responsive to BMPR1B ligands in $\mathrm{FecB}^{\mathrm{B}}$ than in $\mathrm{FecB}^{+}$genotype (Fig. 2A). In sharp contrast, no difference in responsiveness to BMPR $1 \mathrm{~B}$ ligands was observed on $\mathrm{GCs}$ from $\mathrm{FecB}^{+}$and $\mathrm{FecB}^{\mathrm{B}}$ preovulatory follicles.

BMP-4 induced a significant increase $(P<0.05)$ in the proliferation rate of $\mathrm{GCs}$ from $\mathrm{FecB}^{+}$small follicles as assessed by thymidine labeling index (Fig. 2B), but had no effect on GCs from $\mathrm{FecB}^{\mathrm{B}}$ small follicles. GDF-5, probably due to its lower activity compared with BMP-4 as seen on progesterone secretion (Fig. 1A), exerted no significant effect on $\mathrm{GC}$ proliferation in $\mathrm{FecB}^{+}$and $\mathrm{FecB}^{\mathrm{B}}$ genotype. The increase of GC proliferation by IGF-I $(P<0 \cdot 05)$, used as a positive control, was not different in $\mathrm{FecB}^{+}$and $\mathrm{FecB}^{\mathrm{B}}$ genotypes (Fig. 2B).

In conclusion, responsiveness to BMPR1B ligands was altered in $\mathrm{FecB}^{\mathrm{B}}$ compared with $\mathrm{FecB}^{+}$GCs from small antral but not preovulatory follicles.

\section{Specific alteration of BMPR $1 B$ signaling in $\mathrm{FecB}^{B}$ GCs}

Several studies have shown that terminal differentiation of GCs is acquired at a smaller follicular size in $\mathrm{FecB}^{\mathrm{B}}$ than in $\mathrm{FecB}^{+}$genotypes (Henderson et al. 1985, 1987, McNatty et al. 1986, Monniaux et al. 2000). So it can be argued that the decrease in responsiveness of GCs from $\mathrm{FecB}^{\mathrm{B}}$ small follicles might be caused by their more advanced differentiation stage compared with $\mathrm{FecB}^{+}$GCs when isolated from the same follicle size class. To address this issue, we studied the action of two other factors of the TGF $\beta$ family, activin A and TGF $\beta-1$ on GCs of both genotypes. Indeed, biological effects of activin A and TGF $\beta-1$ are independent of the BMPR1B receptor (Miyazono et al. 2001) and both molecules are also known to inhibit progesterone secretion (Shukovski \& Findlay 1990, Miro et al. 1991, Kubota et al. 1994, Ford \& Howard 1997). As expected, activin A and TGF $\beta-1$ exerted strong inhibitory effects on progesterone secretion by ovine GCs in vitro (Fig. 3). These effects were dose-dependent and occurred similarly in both genotypes for GCs from small as well as preovulatory follicles. Moreover, in contrast to BMP-4, activin A and TGF $\beta-1$ had no effect on the proliferation rate of GCs from small follicles of both genotypes (data not shown). Overall, these results indicate that the signaling pathway of BMP factors, but not TGF $\beta-1$ or activin $A$, was specifically altered in $\mathrm{FecB}^{\mathrm{B}}$ GCs from small follicles.

As for BMPR1B ligands, preovulatory follicles appeared less sensitive to activin A and TGF $\beta-1$ action than small follicles. Indeed, the first dose of activin A which was effective in inhibiting progesterone secretion was $10 \mathrm{ng} /$ $\mathrm{ml}$ with GCs from small follicles $(P<0 \cdot 05)$ compared with

\footnotetext{
Figure 1 (opposite) Effects of GDF-5 and BMP-4 on steroidogenesis by FecB ${ }^{+}$GCs from different follicles size classes in vitro. GCs from small antral (1-3 mm in diameter), medium $\left(3 \cdot 5-4.5 \mathrm{~mm}\right.$ ) and preovulatory $(5-7 \mathrm{~mm})$ FecB ${ }^{+}$follicles were cultured for $96 \mathrm{~h}$ in serum-free conditions. (A) Effects on progesterone secretion. Cultures were performed in the absence (control) or presence of different concentrations of dimeric GDF-5 or BMP-4, or $50 \mathrm{ng} / \mathrm{ml}$ monomeric GDF-5 as negative control (m 50). Each combination of treatments was tested in triplicate in each of four independent experiments. Results represent progesterone secretion by 50000 GCs between 48 and 96 h of culture. Data are expressed as percentages (means \pm S.E.M.) of the amount of progesterone secreted by cells cultured in control conditions. ${ }^{\star} P<0 \cdot 05$, small follicles, ligand treated vs control; ${ }^{\$} P<0 \cdot 05$, medium follicles, ligand treated vs control; ${ }^{\#} P<0 \cdot 05$, preovulatory follicles, ligand treated vs control; ${ }^{+} P<0 \cdot 05$, small vs medium or preovulatory follicles. (B) Representative Western immunoblotting analysis of GCs whole cell extract using anti-P450scc antibody. GCs from FecB ${ }^{+}$small or preovulatory follicles were cultured with or without BMP-4 (50 ng/ml) for $96 \mathrm{~h}$. At the end of the culture, GCs were resuspended in lysis buffer and submitted to immunoblotting as described in Materials and Methods. Actin was used as gel loading control. Positions of molecular weight standards are indicated (MW).
} 
$50 \mathrm{ng} / \mathrm{ml}$ with GCs from preovulatory follicles $(P<0 \cdot 05)$. Moreover, at the same dose used, TGF $\beta-1$ was 2- to 3-fold more active with GCs from small follicles compared with preovulatory follicles (Fig. 3).
Thus, as for BMPR1B ligands, activin A and TGF $\beta-1$ responsiveness decreased during terminal follicular development in ewes. However, in contrast, it was not affected by the presence of the Booroola mutation.

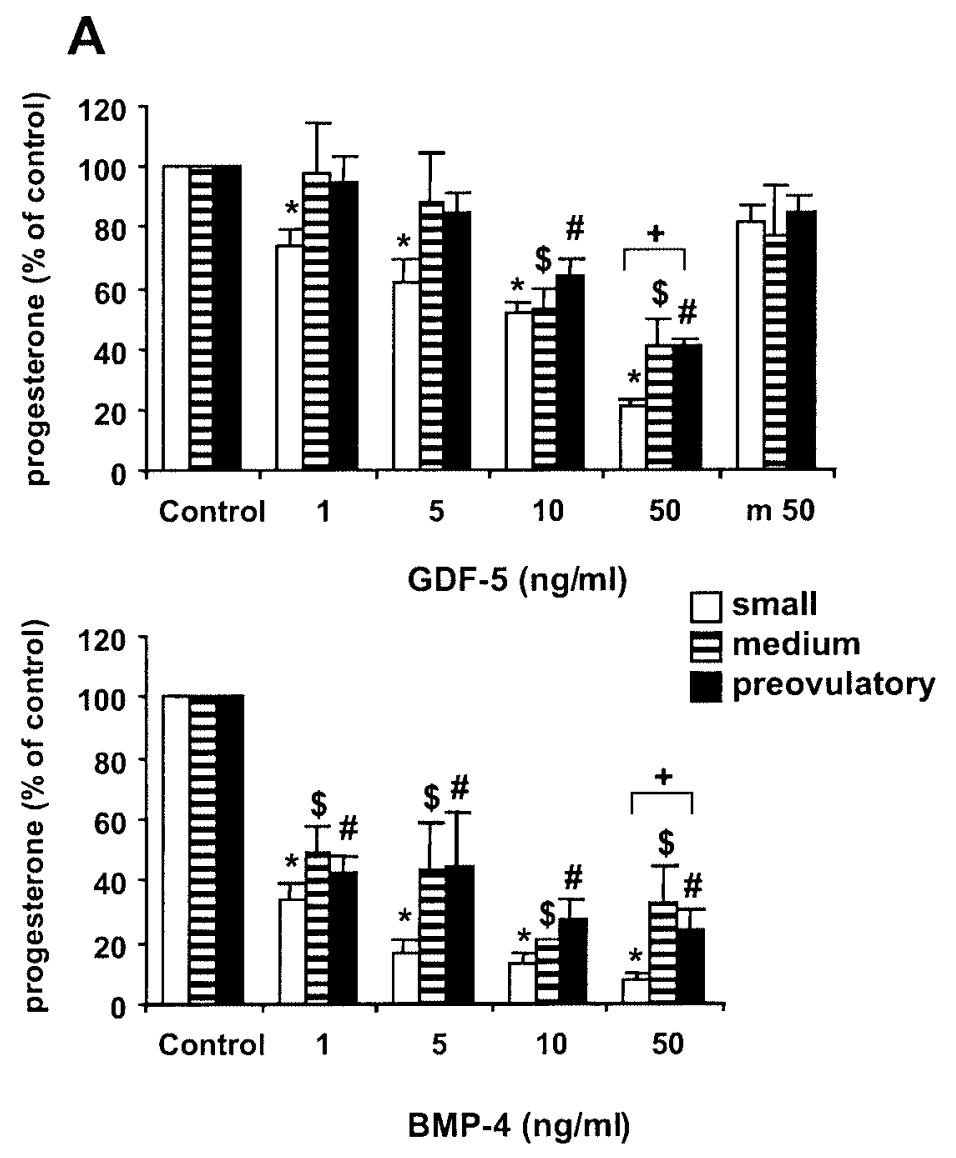

B

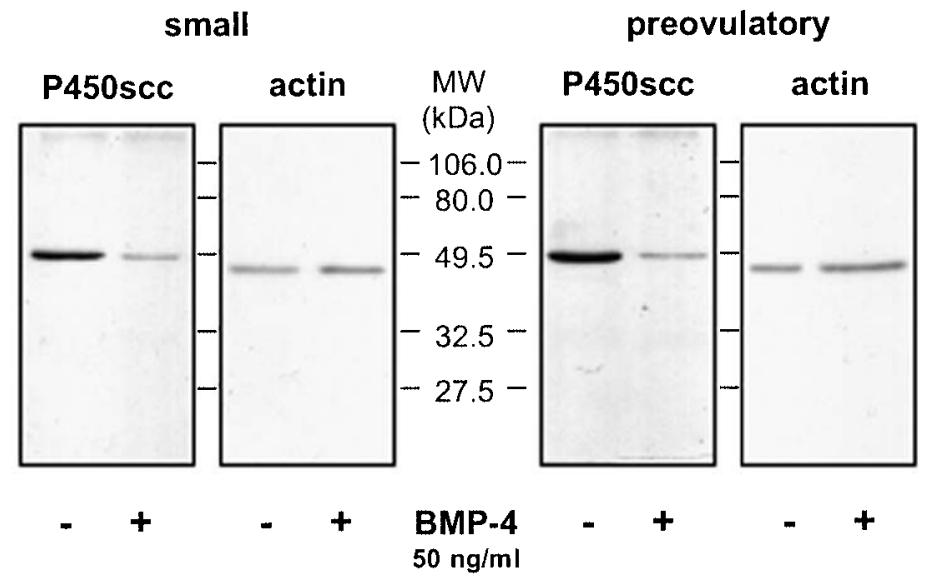


Consequence of the Q249R substitution on BMPR1B signaling

By using the HEK-293 cell line, we investigated the capacity of the Booroola form of the BMPR1B(QR) receptor to trigger the BMP-4 signaling pathway. The HEK-293 cell line was transiently transfected with a BMP-specific reporter construct (12GCCG-lux) (Kusanagi et al. 2000), with or without vectors encoding the human BMPR2, and with either the wild-type form of ovine BMPR1B or the BMPR1B(QR). After transfection, HEK-293 cells were treated for $24 \mathrm{~h}$ with or without $100 \mathrm{ng} / \mathrm{ml}$ BMP-4. The results (Fig. 4) show that HEK293 cells were endogenously BMP-responsive and that this response was not affected by overexpression of BMP receptor type II alone. When BMPR2 and BMPR 1B were co-expressed to allow for newly formed receptor complexes, BMP-4 enhanced luciferase activity by $2 \cdot 6-$ fold over basal levels. In the presence of BMPR1B(QR) receptor, basal luciferase activity was significantly increased $(P<0 \cdot 01)$ and no activation of luciferase activity was observed in the presence of BMP-4. Thus, signaling activity of overexpressed BMPR1B was altered by the Booroola mutation.

\section{Discussion}

In this study and for the first time, we have performed an overall analysis of the effects of different elements of the TGF $\beta$ /BMP system on ovine GCs from different follicular size classes in vitro. Moreover, we have investigated the functional consequences of the Q249R mutation in the BMPR1B receptor of Booroola ewes. Our data led to the conclusion that: (i) BMP/TGF $\beta$ factors exerted a strong inhibitory effect on progesterone secretion by GCs from small antral follicles in the ewe - this inhibitory effect decreasing during terminal follicular growth; (ii) the responsiveness to $\mathrm{BMPR} 1 \mathrm{~B}$ ligands was altered in $\mathrm{FecB}^{\mathrm{B}}$ compared with $\mathrm{FecB}^{+}$GCs from small antral but not preovulatory follicles; (iii) the TGF $\beta-1$ and activin A inhibition of progesterone secretion was similar in GCs from $\mathrm{FecB}^{+}$and $\mathrm{FecB}^{\mathrm{B}}$ genotypes, strongly suggesting that BMPR1B signaling was specifically altered in Booroola follicles; and (iv) the Booroola mutation Q249R was able to directly alter the signaling pathway triggered by BMPR1B receptor. Overall, these data strongly suggest that the hyperprolificacy phenotype of Booroola ewes is associated with an altered BMPR1B-dependent signaling.

In the rat, Shimasaki et al. (1999) have shown that BMP-4 and BMP-7 inhibit progesterone but enhance estradiol secretion by GCs. In our experimental conditions, secretion of estradiol by ovine GCs in vitro is low and not stimulated by BMPs. So, our ovine model does not allow assessment of the effects of the Q249R mutation on estradiol secretion. Nevertheless, in vivo, it is proposed that BMP factors would impair premature luteinization of ovarian follicles (Shimasaki et al. 1999). The present data have shown a decrease in the responsiveness of GCs from preovulatory, compared with small, follicles to the effects of BMPR1B ligands, as well as TGF $\beta-1$ and activin A, suggesting that the anti-luteinizing effects of these factors decrease during terminal follicular growth. Moreover, from our results, it is strongly suggested that Q249R substitution is associated with a loss of responsiveness of BMPR1B receptor to BMP ligands. Then, in Booroola ewes, Q249R substitution would impair the antiluteinizing function of BMPR1B pathway in growing follicles, leading to an advanced differentiation of GCs and an advanced maturation of follicles.

Surprisingly, the differential effect of BMP-4 and GDF-5 between genotypes was observed only on GCs isolated from small but not preovulatory follicles. This result could be partly explained by some redundancy of $\mathrm{BMP}$ receptors. In particular, BMPR $1 \mathrm{~A}$, another receptor for BMP-4 and GDF-5 (ten Dijke et al. 1994, Nishitoh et al. 1996, Yi et al. 2000), was also shown to be expressed in ovine GCs (Souza et al. 2002). One could hypothesize that expression and/or activation of BMPR1B and BMPR1A would be predominant in small and preovulatory follicles respectively. Then, the Booroola mutation would have an effect only on small follicles. However, by in situ hybridization or immunohistochemistry, Wilson et al. (2001) and Souza et al. (2002) did not report any striking difference in expression of BMPR1B in the different categories of ovine follicles. Moreover, by RTPCR, we did not observe any difference in expression of these two receptors between GCs isolated from ovine small or preovulatory follicles (S Fabre, unpublished observations). Alternatively, one could also hypothesize that the Q249R mutation would have a consequence on the functionality of BMPR1B only in the presence of another partner that would be expressed and/or functional in small but not preovulatory follicles. The existence of such a factor and its consequences on the signaling pathway should now be investigated.

Whether the Booroola mutation leads to a partial or a complete alteration of BMPR1B function remains unknown. In $\mathrm{GCs}$ from $\mathrm{FecB}^{\mathrm{B}}$ small follicles, inhibition of progesterone secretion by BMPR1B ligands was largely reduced but still existed, suggesting a possible partial loss-of-function mutation. However, the residual response of GCs to GDF-5 and BMP-4 could be due to BMPR1A signaling. From transient transfection experiments of HEK-293 cells, the Q249R mutation seems to entirely abrogate the ability of BMPR $1 \mathrm{~B}$ to respond to the BMP-4 stimulation, suggesting a complete loss of responsiveness of $\mathrm{FecB}^{\mathrm{B}}$ BMPR1B to its ligands. Nevertheless, in these experiments, we have also observed a significant increase in the luciferase basal activity triggered by the $\mathrm{FecB}^{\mathrm{B}}$ form of BMPR1B, indicating that the Q249R substitution could act as a constitutively active mutation in BMPR1B. If this last observation is physiologically relevant, then 
A small

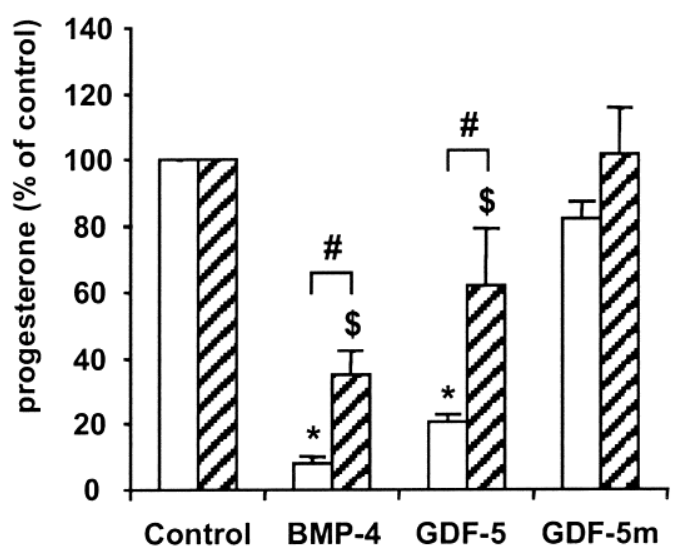

preovulatory

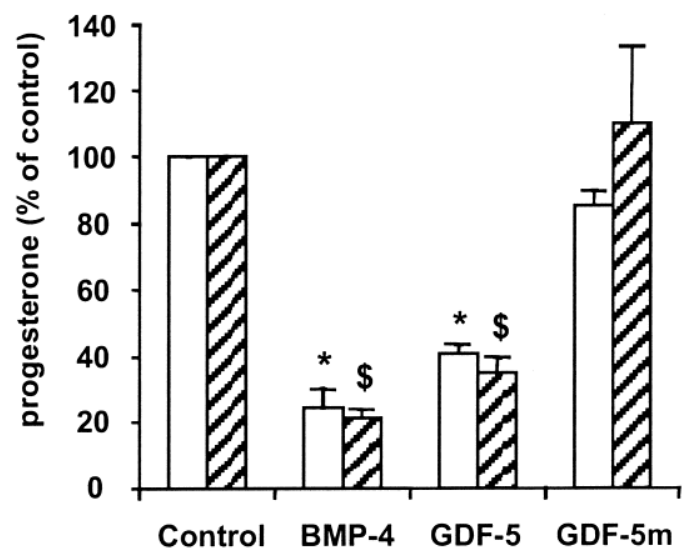

\section{B small}

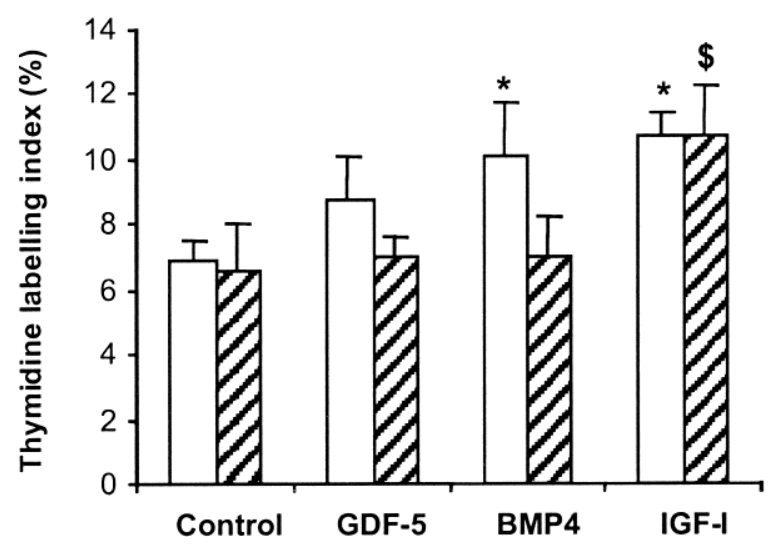

Figure 2 Eff05063 ect of the Booroola mutation on GCs' responsiveness to BMPR1B ligands in vitro. GCs were collected from $\mathrm{FecB}^{+}$(open bars) and $\mathrm{FecB}^{\mathrm{B}}$ (hatched bars) small antral $\left(1-3 \mathrm{~mm}\right.$ in diameter) and preovulatory $\left(\mathrm{FecB}^{+}\right.$: 5-7 mm, FecB ${ }^{\mathrm{B}}$ : $3.5-4.5 \mathrm{~mm}$ ) follicles. (A) Progesterone secretion. GCs were cultured for $96 \mathrm{~h}$ in serum-free conditions in the presence or absence (control) of $50 \mathrm{ng} / \mathrm{ml}$ human recombinant dimeric GDF-5 or BMP-4, or monomeric GDF-5 as negative control (GDF-5m) in the culture medium. Each combination of treatments was tested in triplicate in each of four independent experiments. Results represent progesterone secretion by GCs between 48 and $96 \mathrm{~h}$ of culture. Data are expressed as percentages (means \pm S.E.M.) of the amount of progesterone secreted by cells cultured in the absence of BMPR1B ligands. (B) Cell proliferation. Data represent the thymidine labeling index (see Materials and Methods) of GCs from $\mathrm{FecB}^{+}$and $\mathrm{FecB}^{\mathrm{B}}$ small follicles after $48 \mathrm{~h}$ of culture in the absence or presence of GDF-5 $(50 \mathrm{ng} / \mathrm{ml})$, BMP-4 $(50 \mathrm{ng} / \mathrm{ml})$ or IGF-I $(10 \mathrm{ng} / \mathrm{ml}) .{ }^{*} P<0 \cdot 05$, FecB ${ }^{+}$ligand treated vs control;

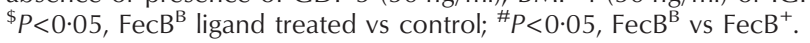

ovarian progesterone secretion of $\mathrm{FecB}^{\mathrm{B}}$ ewes should be constitutively inhibited. BMPR1B is known to be expressed in ovine corpora lutea (Wilson et al. 2001, Souza et al. 2002) but physiological studies have never demon- strated a significant difference in progesterone secretion of Booroola compared with wild-type ewes (Baird \& Campbell 1998). In contrast to hyperprolificacy of Booroola ewes, bmpr1b-/-female mice are sterile, 

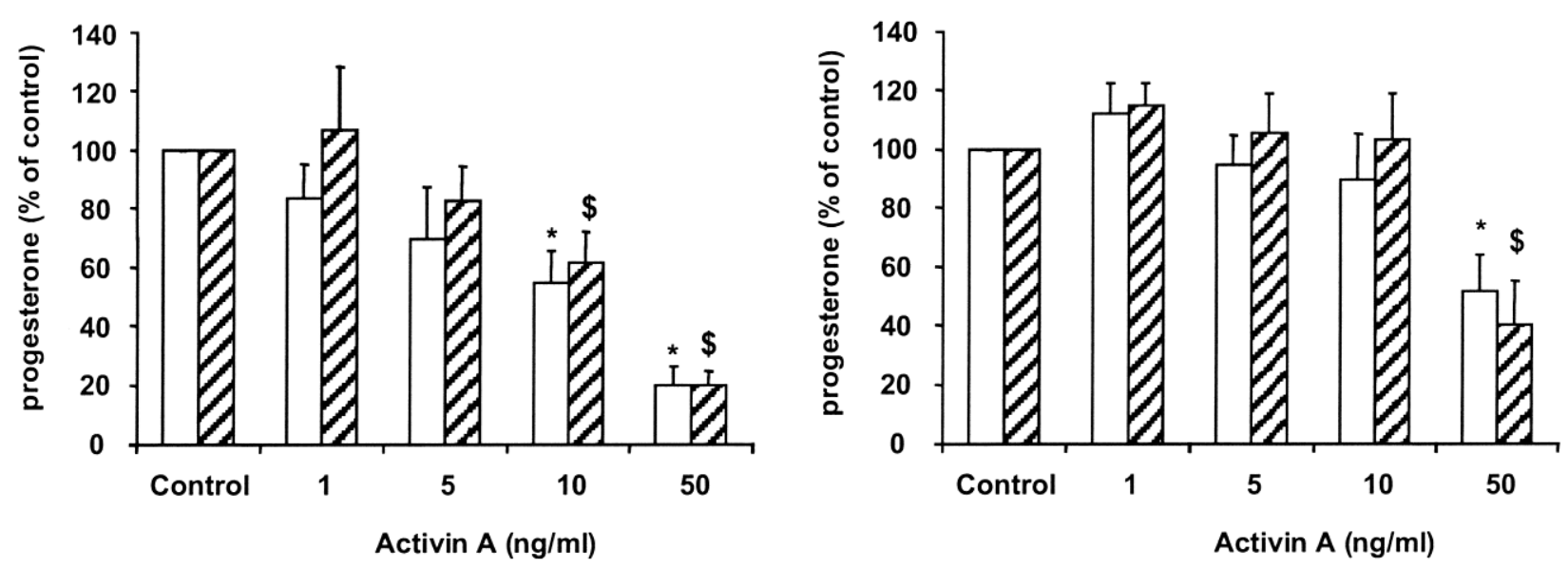

small

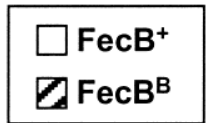

preovulatory
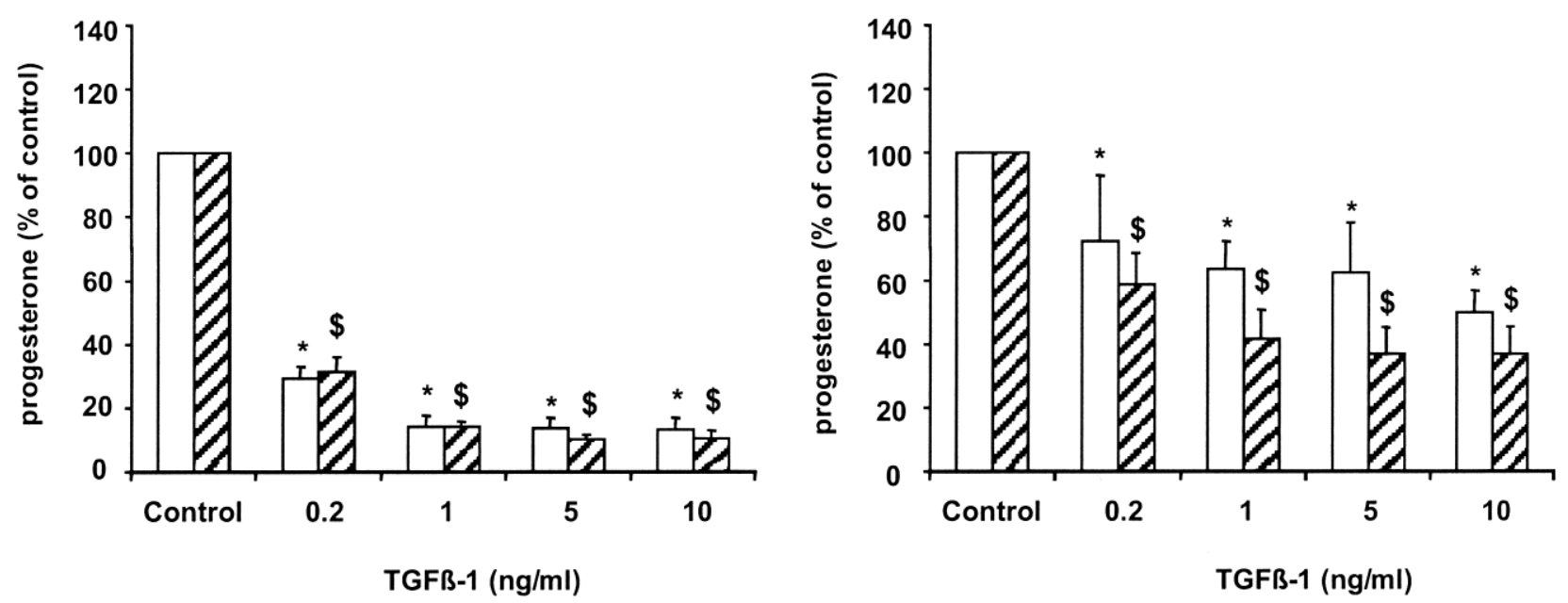

Figure 3 Effect of the Booroola mutation on GCs' responsiveness to activin A and TGF- $\beta 1$ in vitro. Experimental conditions were the same as in Fig. 2A. GCs from $\mathrm{FecB}^{+}$and $\mathrm{FecB}^{\mathrm{B}}$ small and preovulatory follicles were cultured in the absence (control) or presence of increasing amounts of recombinant human activin A (upper panels) or TGF- $\beta 1$ (lower panels). Data are expressed as percentages of the amount of progesterone secreted by cells cultured in the absence of TGF- $\beta$ family ligands. ${ }^{\star} P<0 \cdot 05$, FecB ${ }^{+}$ligand treated vs control; ${ }^{\$} P<0 \cdot 05$, FecB ${ }^{B}$ ligand treated vs control.

cumulus expansion and embryo implantation being dramatically altered (Yi et al. 2001). Actually, data on the effects of a natural point mutation in sheep and of an experimental deletion in the mouse are difficult to reconcile. In particular, consequences of inactivation of one or both copies of bmp15 are completely different in mouse and sheep (Galloway et al. 2000, Yan et al. 2001). These discrepancies are probably due to species differences, and/or to the nature of the alteration (point mutation vs deletion). Nevertheless, further studies are needed to assess the degree of alteration of BMPR $1 \mathrm{~B}$ receptor in Booroola ewes.
The physiological ligands of BMPR1B remain to be determined in sheep ovary. BMP-4 and BMP-7 were shown to be expressed by follicular theca cells in the rat (Shimasaki et al. 1999). BMP-3 has been shown to be expressed by human granulosa-luteal cells (Jaatinen et al. 1996), and the oocyte expresses BMP-6, GDF-9 and BMP-15 (for a review see Elvin et al. 2000). Preliminary RT-PCR experiments indicate the presence of mRNA for BMP-2, BMP-4, BMP-6, BMP-7, GDF-9 and BMP-15 in antral ovine whole follicles (data not shown). Otsuka et al. (2001) have suggested recently that among the BMP ligands expressed by the follicle, BMP-6 repre- 


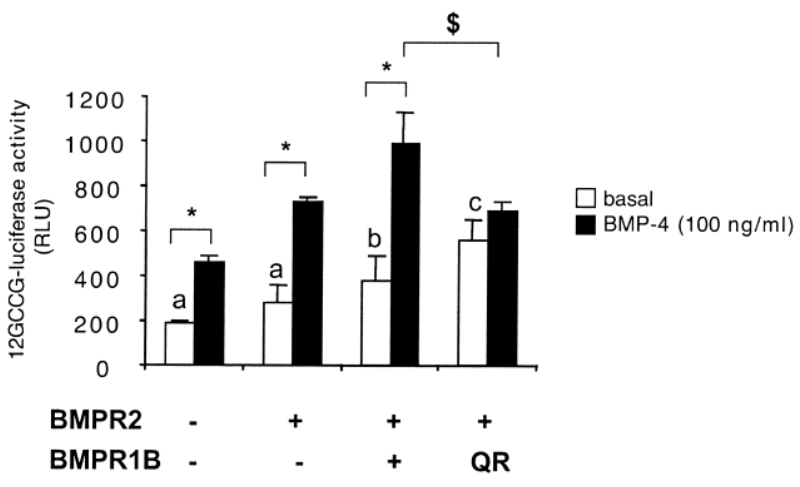

Figure 4 Effect of the Booroola mutation on BMPR1B signaling activity. HEK-293 cells growing in $10 \%$ FCS were transiently transfected with the 12 GCCG-lux reporter construct and different combinations of plasmids expressing human BMPR2, ovine BMPR1B with or without the Q249R mutation (QR). After transfection, cells were cultured $24 \mathrm{~h}$ in serum-free conditions in the absence (basal) or presence of $100 \mathrm{ng} / \mathrm{ml}$ BMP-4 before luciferase assays. Luciferase activity is expressed as relative light units (RLU). Data represent means \pm S.E.M. of measurements performed in three independent experiments. ${ }^{*} P<0 \cdot 05, \mathrm{BMP}-4$ vs basal; ${ }^{\$} P<0 \cdot 01$. a, b, c denote significant statistical differences in basal activities, $P<0.05$.

sents the more likely candidate ligand for BMPR1B signaling. To test the hypothesis that one of these oocytederived BMP factors acts through BMPR1B, it would be of great interest to compare their biological effects on GCs from $\mathrm{FecB}^{+}$and $\mathrm{FecB}^{\mathrm{B}}$ small antral follicles.

All the factors tested, acting through (BMP-4 and GDF-5) or independently of (TGF $\beta-1$ or activin A) BMPR1B receptor, exerted a strong inhibitory action on progesterone secretion by ovine GCs in vitro. BMP-7 and the three oocyte-derived BMP family members also strongly inhibit progesterone secretion by folliclestimulating hormone-treated rodent granulosa cells in vitro (Shimasaki et al. 1999, Otsuka et al. 2000, 2001, Vitt et al. 2000). This suggests a certain redundancy of the antiluteinizing action of the TGF $\beta$ /BMP system in the ovary in vivo and raises the question of the relative importance of each pathway for controlling terminal follicular maturation and ovulation rate. Recent findings have shown that hyperprolificacy of Inverdale and Hanna ewes was due to loss-of-function mutations in the BMP15 gene (Galloway et al. 2000). Overall, the Booroola, Inverdale and Hanna genetic models of hyperprolificacy in sheep strongly suggest that the BMP system plays a key role in folliculogenesis and that a decrease in BMP signaling positively regulates the number of ovulatory follicles.

\section{Acknowledgements}

We are grateful to Dr B Nguyen (Genetics Institute Inc., Cambridge, MA, USA) for his gift of recombinant human
BMP-4, Dr J Massagué (Sloan Kettering Institute, New York, USA) for kindly providing us the human BMPR2 expression plasmid and Dr M Kawabata (Cancer Institute of the Japanese Foundation for Cancer Research, Tokyo, Japan) for his gift of the 12GCCG-lux reporter construct. We also thank Drs $\mathrm{H} \mathrm{H}$ Peter and A Hinnen from Ciba-Geigy for providing recombinant human IGF-I. We are also very grateful to L Bodin and the Boomarov team for Booroola sheep production, breeding, and characterization. We also thank F Dupont and the staff of the ovine experimental unit in Nouzilly for their collaboration in experimental design. This research was supported by Institut National de la Recherche Agronomique AIP grants Booroola and Génomes et Fonction and by the European Union AIR contract CT 920232. A P was supported by a French fellowship from the Région Centre.

\section{References}

Baird DT \& Campbell BK 1998 Follicle selection in sheep with breed differences in ovulation rate. Molecular and Cellular Endocrinology 145 89-95.

Campbell BK, Scaramuzzi RJ \& Webb R 1996 Induction and maintenance of oestradiol and immunoreactive inhibin production with FSH by ovine granulosa cells cultured in serum-free media. Journal of Reproduction and Fertility 106 7-16.

Davis GH, Montgomery GW, Allision AJ, Kelly RW \& Bray AR 1982 Segregation of a major gene influencing fecundity in progeny of Booroola sheep. New Zealand Journal of Agricultural Research 25 525-529.

Derynck R \& Feng XH 1997 TGF-beta receptor signaling. Biochimica et Biophysica Acta 1333 F105-F150.

ten Dijke P, Yamashita H, Sampath TK, Reddi AH, Estevez M, Riddle DL, Ichijo H, Heldin CH \& Miyazono K 1994 Identification of type I receptors for osteogenic protein-1 and bone morphogenetic protein-4. Journal of Biological Chemistry 269 16985-16988.

Elvin JA, Yan C \& Matzuk MM 2000 Oocyte-expressed TGF-beta superfamily members in female fertility. Molecular and Cellular Endocrinology 159 1-5.

Ford JJ \& Howard HJ 1997 Activin inhibition of estradiol and progesterone production in porcine granulosa cells. Journal of Animal Science 75 761-766.

Galloway SM, McNatty KP, Cambridge LM, Laitinen MP, Juengel JL, Jokiranta TS, McLaren RJ, Luiro K, Dodds KG, Montgomery GW et al. 2000 Mutations in an oocyte-derived growth factor gene (BMP15) cause increased ovulation rate and infertility in a dosage-sensitive manner. Nature Genetics 25 279-283.

Henderson KM, Kieboom LE, McNatty KP, Lun S \& Heath D 1985 Gonadotrophin-stimulated cyclic AMP production by granulosa cells from Booroola $\times$ Romney ewes with and without a fecundity gene. Journal of Reproduction and Fertility 75 111-120.

Henderson KM, McNatty KP, O'Keeffe LE, Lun S, Heath DA \& Prisk MD 1987 Differences in gonadotrophin-stimulated cyclic AMP production by granulosa cells from Booroola $\times$ Merino ewes which were homozygous, heterozygous or non-carriers of a fecundity gene influencing their ovulation rate. Journal of Reproduction and Fertility 81 395-402.

Jaatinen R, Rosen V, Tuuri T \& Ritvos O 1996 Identification of ovarian granulosa cells as a novel site of expression for bone morphogenetic protein-3 (BMP-3/osteogenin) and regulation of BMP-3 messenger ribonucleic acids by chorionic gonadotropin in cultured human granulosa-luteal cells. Journal of Clinical Endocrinology and Metabolism 81 3877-3882. 
Kubota T, Kamada S, Taguchi M \& Aso T 1994 Autocrine/paracrine function of transforming growth factor-beta 1 in porcine granulosa cells. Human Reproduction 9 2118-2122.

Kusanagi K, Inoue H, Ishidou Y, Mishima HK, Kawabata M \& Miyazono K 2000 Characterization of a bone morphogenetic protein-responsive Smad-binding element. Molecular Biology of the Cell 11 555-565.

Liu F, Ventura F, Doody J \& Massague J 1995 Human type II receptor for bone morphogenic proteins (BMPs): extension of the two-kinase receptor model to the BMPs. Molecular and Cellular Biology 15 3479-3486.

McNatty KP, Lun S, Heath DA, Ball K, Smith P, Hudson NL, McDiarmid J, Gibb M \& Henderson KM 1986 Differences in ovarian activity between Booroola $\times$ Merino ewes which were homozygous, heterozygous and non-carriers of a major gene influencing their ovulation rate. Journal of Reproduction and Fertility 77 193-205

Miro F, Smyth CD \& Hillier SG 1991 Development-related effects of recombinant activin on steroid synthesis in rat granulosa cells. Endocrinology 129 3388-3394.

Miyazono K 1999 Signal transduction by bone morphogenetic protein receptors: functional roles of Smad proteins. Bone 25 91-93.

Miyazono K, Kusanagi K \& Inoue H 2001 Divergence and convergence of TGF-beta/BMP signaling. Journal of Cellular Physiology 187 265-276.

Monniaux D \& Pisselet C 1992 Control of proliferation and differentiation of ovine granulosa cells by insulin-like growth factor-I and follicle-stimulating hormone in vitro. Biology of Reproduction 46 109-119.

Monniaux D, Monget P, Pisselet C, Fontaine J \& Elsen JM 2000 Consequences of the presence of the Booroola $\mathrm{F}$ gene on the intraovarian insulin-like growth factor system and terminal follicular maturation in Mérinos d'Arles ewes. Biology of Reproduction $\mathbf{6 3}$ 1205-1123.

Mulsant P, Lecerf F, Fabre S, Schibler L, Monget P, Lanneluc I, Pisselet C, Riquet J, Monniaux D, Callebaut I et al. 2001 Mutation in bone morphogenetic protein receptor-IB is associated with increased ovulation rate in Booroola Merino ewes. PNAS 98 5104-5109.

Nishitoh H, Ichijo H, Kimura M, Matsumoto T, Makishima F, Yamaguchi A, Yamashita H, Enomoto S \& Miyazono K 1996 Identification of type I and type II serine/threonine kinase receptors for growth/differentiation factor-5. Journal of Biological Chemistry 271 21345-21352.

Otsuka F, Yao Z, Lee T, Yamamoto S, Erickson GF \& Shimasaki S 2000 Bone morphogenetic protein-15. Identification of target cells and biological functions. Journal of Biological Chemistry 275 39523-39528.

Otsuka F, Moore RK \& Shimasaki S 2001 Biological function and cellular mechanism of bone morphogenetic protein-6 in the ovary. Journal of Biological Chemistry 276 32889-32895.
Piper LR, Bindon BM \& Davis GH 1985 The single gene inheritance of the high litter size of the Booroola Merino. In Genetics of Reproduction in Sheep, pp 115-125. Eds RB Land \& DW Robinson. London: Butterworths.

Saumande J 1991 Culture of bovine granulosa cells in a chemically defined serum-free medium: the effect of insulin and fibronectin on the response to FSH. Journal of Steroid Biochemistry and Molecular Biology 38 189-196.

Shimasaki S, Zachow RJ, Li D, Kim H, Iemura S, Ueno N, Sampath K, Chang RJ \& Erickson GF 1999 A functional bone morphogenetic protein system in the ovary. PNAS 96 7282-7287.

Shukovski L \& Findlay JK 1990 Activin-A inhibits oxytocin and progesterone production by preovulatory bovine granulosa cells in vitro. Endocrinology 126 2222-2224.

Souza CJ, MacDougall C, Campbell BK, McNeilly AS \& Baird DT 2001 The Booroola $(\mathrm{FecB})$ phenotype is associated with a mutation in the bone morphogenetic receptor type $1 \mathrm{~B}$ (BMPR1B) gene. Journal of Endocrinology 169 R1-R6.

Souza CJ, Campbell BK, McNeilly AS \& Baird DT 2002 Effect of bone morphogenetic protein 2 (BMP2) on oestradiol and inhibin A production by sheep granulosa cells, and localization of BMP receptors in the ovary by immunohistochemistry. Reproduction $\mathbf{1 2 3}$ 363-369.

Vitt UA, Hayashi M, Klein C \& Hsueh AJ 2000 Growth differentiation factor-9 stimulates proliferation but suppresses the follicle-stimulating hormone-induced differentiation of cultured granulosa cells from small antral and preovulatory rat follicles. Biology of Reproduction 62 370-377.

Wilson T, Wu XY, Juengel JL, Ross IK, Lumsden JM, Lord EA, Dodds KG, Walling GA, McEwan JC, O'Connell AR et al. 2001 Highly prolific Booroola sheep have a mutation in the intracellular kinase domain of bone morphogenetic protein IB receptor (ALK-6) that is expressed in both oocytes and granulosa cells. Biology of Reproduction 64 1225-1235.

Yan C, Wang P, DeMayo J, DeMayo FJ, Elvin JA, Carino C, Prasad SV, Skinner SS, Dunbar BS, Dube JL et al. 2001 Synergistic roles of bone morphogenetic protein 15 and growth differentiation factor 9 in ovarian function. Molecular Endocrinology 15 854-866.

Yi SE, Daluiski A, Pederson R, Rosen V \& Lyons KM 2000 The type I BMP receptor BMPRIB is required for chondrogenesis in the mouse limb. Development 127 621-630.

Yi SE, LaPolt PS, Yoon BS, Chen JY, Lu JK \& Lyons KM 2001 The type I BMP receptor BmprIB is essential for female reproductive function. PNAS 98 7994-7999.

Received in final form 12 February 2003

Accepted 13 February 2003 